\title{
Obituary Edward G Jones
}

\author{
Neuropsychopharmacology (2012) 37, 2888; \\ doi: 10.1038/npp.2012.196
}

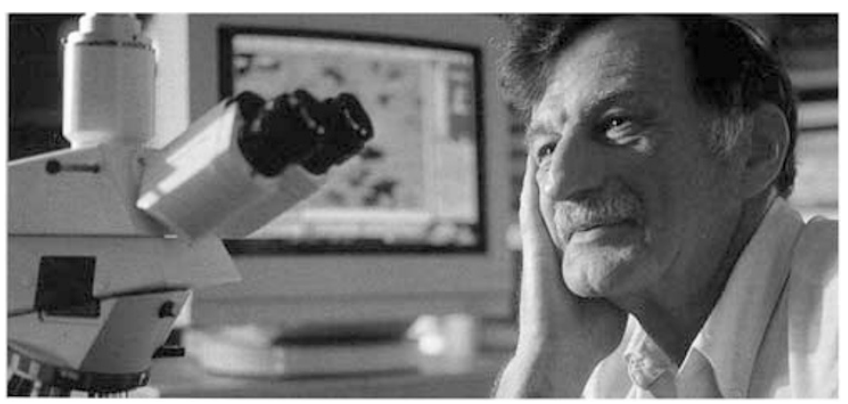

Edward (Ted) G Jones died unexpectedly on 6 June 2011 while attending a meeting at UCLA Medical Center. He was 72 years of age.

Born near Wellington, New Zealand in 1939 and raised under very modest circumstances Ted defied the odds by attending Medical School at the University of Otago where he graduated in 1962. He then worked for a year as a house officer in a community hospital and began working toward an academic medical career at the University of Otago where he was increasingly drawn to basic science. He then obtained a prestigious fellowship to train in Neuroanatomy at the University of Oxford with the eminent neuroanatomist Tom Powell, arriving there in 1965 with his wife Sue and obtaining his $\mathrm{PhD}$. in 1968. His three-year doctoral training period produced 23 papers many of which were of seminal importance. After serving as a lecturer at Oxford and back in New Zealand where he was Associate Professor in the Anatomy Department at Otago, Ted moved to the United States where he joined the Faculty at Washington University in St. Louis and through a period of prodigious productivity rapidly established himself as one of the leading figures in Neuroanatomy and the emerging new interdisciplinary field of Neuroscience. In 1984 he moved to UC Irvine where he took over as Chair of the Department of Anatomy and Neurobiology. During his time at Irvine Ted also ran a laboratory in Japan at the Riken Institute. In 1998, Ted moved to the University of California at Davis where he became Director of the Center for Neuroscience, a position that he held till his retirement in 2010. During this time he presided over an extraordinary period of growth and development of the Center, transforming it from one with a primary cognitive and systems focus to one that spanned the full range of approaches from molecular, cellular and systems to behavioral and cognitive neuroscience.
Ted Jones distinguished himself in many areas of neuroscience. He was unquestionably the world authority on the Thalamus, producing a remarkable two-volume book filled with his own photomicrographs and illustrations. He was a pioneer of the study of cortico-cortical circuitry and the subpopulations of neurons that comprise local cortical circuits and of neuroplasticity in the cortex and thalamus that helped define the field. It has been said that during his career he studied every area of the brain with every important new technique available to him, with extraordinary rigor and a conceptual clarity and sense of perspective that few in the field have attained. He was a leader of the Human Brain Project, an NIH funded neuroinformatics initiative that has led to the development of accessible databases and atlases of human and animal brain anatomy. He was also a pioneer of modern human postmortem analyses of psychiatric diseases, conducting the first modern immunohistochemical studies of postmortem tissue in schizophrenia and introducing the use of array technologies to study gene expression in the postmortem brains of individuals with schizophrenia and mood disorders. The modern view of schizophrenia as a disorder of cortical microcircuitry evolved out of this work, which was conducted through his role in the Pritzker Consortium. He was also an important historian of neuroscience, having trained in the traditions of the classic neuroanatomists and lived through the emergence of the field in the 1960s and its subsequent explosion of knowledge during the next 40 years.

Ted Jones was a scientist's scientist, a discerning, traditional scholar who could always be found at his microscope, and who inspired and led his fellow neuroscientists and recruits by example. He had a very broad, integrative and inclusive view of neuroscience that is reflected in the Center that he built at UC Davis. He authored over 400 papers and over 20 books including 2 editions of his volumes on the Thalamus and garnered many accolades during his career, including election to the National Academy of Sciences, president of the Society of Neuroscience and the Cajal Club and Fellow of the ACNP.

Ted was also a loving husband, a father of two, grandfather of three, a collector of books and art, and a farmer and winemaker. He leaves a remarkable scientific legacy and impact on all those who had the privilege of knowing and working with him.

Cameron S Carter ${ }^{1}$

${ }^{1}$ Director, Center for Neuroscience, University of California,

Davis, Sacramento, CA, USA

E-mail: cameron.carter@ucdmc.ucdavis.edu 